\title{
Groundwater arsenic geochemical cycling and risk along different flood plains of Pakistan
}

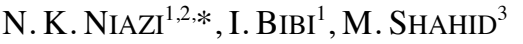 \\ ${ }^{1}$ University of Agriculture Faisalabad, Pakistan (*Email: \\ nabeelkniazi@gmail.com) \\ ${ }^{2}$ University of Southern Queenland, Queensland, Australia \\ ${ }^{3}$ COMSATS University Islamabad, Vehari, Pakistan
}

\begin{abstract}
Globally, groundwater arsenic (As) contamination, expecially in South and Southeast Asian countries, including Pakistan represents a potential environmental and public health issue. Here, we systemetically undertook groundwater samples along different river floodplains of Pakistan (e.g., River Ravi and River Satluj) and examined the total As and other water quality attributes. The groundwater along River Ravi and River Satluj flood plains was highly As-contaminated with up to $71 \%$ of the wells exceeding As concentration (BDL to 234 $\mu \mathrm{g} \mathrm{L}^{-1}$ ) above the World Health Organization safe limit (WHO, $10 \mu \mathrm{g} \mathrm{L}^{-1}$ ). On an average, As content in shallow wells (9-40 m; As: $6.3 \mu \mathrm{g} \mathrm{L}^{-1}$ ) was below the WHO limit, providing a safe zone for pumping of drinking water. In contrast, deep wells (41-90 m; As: $56 \mu \mathrm{g} \mathrm{L}^{-1}$ and > $90 \mathrm{~m}$; As: $33 \mu \mathrm{g} \mathrm{L}^{-1}$ ) were considered to be unsafe. The hydrogeochemical cycling of As was controlled by saline type of groundwater $\left(\mathrm{Na}-\mathrm{SO}_{4}\right.$ and $\left.\mathrm{Na}-\mathrm{Ca}-\mathrm{HCO}_{3}\right)$ with alkaline $\mathrm{pH}$ (pH 7.54 to 9.10 ), and iron oxides were thought to be major minerals governing As retention/release cycling. The elevated As contamination, mainly along Ravi River and River Satluj flood plains, can possibly be ascribed to reduced water flow in these rivers causing negligibale groundwater recharge, and as such triggering As release by oxidation/reduction of iron-rich underground sediments.
\end{abstract}

